\title{
EFFECT OF DEBT TO EQUITY RATIO AND FIRM SIZE OF RETURN ON ASSETS ON MANUFACTURING COMPANY IN INDONESIA STOCK EXCHANGE
}

\author{
DR. JUNAIDI AND MUKSAL
}

\begin{abstract}
This study aims to analyze the effect of Debt to Equity Ratio (DER) and Firm Size on Profitability proxy with Return on Asset (ROA) in Manufacturing company on the Indonesian Stock Exchange 2017-2019. The sample population in this study contains Manufacturing companies listed on the Indonesia Stock Exchange The number of companies used in this study were 127 company samples. The research data is quantitative data obtained from the quarterly financial report of Manufacture Companies. Data analysis using simple linear analysis with 5\% significance level which aims to obtain how the overall influence of the relationship between Debt to Equity Ratio (DER), Firm Size variable and Return on Asset (ROA). The results showed that the variable Debt to Equity Ratio (DER) has a negative and significant effect on Return on Asset (ROA) with a value $t$ greater than 0.005 and Firm Size has a negative and significant effect on Return on Asset (ROA) with a value $t$ greater than 0.005. High DER ratio can give a picture of the negative effect on profitability and High Firm Size ratio can give a picture of the negative effect on profitability of Manufacture Company.
\end{abstract}

\section{INTRODUCTION}

Every company always needs funds in order to meet the needs of daily operations and to develop the company. The required funds are in the form of working capital and for the purchase of fixed assets. To meet these funding needs, companies must be able to find sources of funds with a composition that produces the cheapest costs. (Sutrisno, 2017: 3).

In the industrial world a very tight competition, leading to competitive advantage has grown and involved on the importance of the company's financial performance. Therefore it is very important to learn more about the study of the company's financial performance. ROA is an indicator to measure the company's financial performance and is a profitability ratio that is used to measure the effectiveness of a company in generating profits by utilizing its total assets. $\mathrm{ROA}$ is the ratio between profit after tax to total assets.

Basically, if a company increases the amount of debt as a source of funds that may increase financial risk, if the company is unable to manage the proceeds of the debt in a productive, it can be a negative influence and impact on the declining profitability of the company. Conversely, if the debt can be managed properly and used for productive investment projects, it can have a positive effect and have an impact on increasing the company's profitability. Each company must have the same goal of obtaining the maximum profit that can be said to have a good profitability. To measure the success of a company that is effective and efficient in generating

Received by the editors February 9, 2021. Accepted by the editors october 19, 2021.

Keywords: Debt to Equity, Firm Size, Return on Asset, Manufacture Company.

JEL Classification: G140.

Dr. Junaidi, M.Ed., M.A, Lecturer at the Islamic Economics and Business Faculty Institut Agama Islam Negeri Langsa, Aceh Indonesia. E-mail: junaidi.erda@gmail.com.

Muksal, M.E.I. *(Corresponding Author), Lecturer at the Islamic Economics and Business Faculty, Universitas Islam Negeri Ar-Raniry Banda Aceh, Aceh Indonesia. E-mail: ewa.maruszewska@ue.katowice.pl.

This paper is in final form and no version of it will be submitted for publication elsewhere. 
profits is not only seen from the size of the amount of profit obtained but can be seen from its profitability.

Companies are considered risky if they have large debts in their capital structure. Decision of companies are choosing to use large amounts of debt to finance its operational activities rather than their own capital, will have an impact on the company profitability. The use of increasingly large debt caused interest expense and principal on debt that must be paid by the company is also getting bigger, which adversely affects the profit generated by the company.

Company size is an important factor in determining a company's financial performance. Companies that have a larger company size have an influence on company profitability. This is because larger companies have several competitive advantages, including market power where large companies can charge high prices for their products, economies of scale that impact on cost savings because of this. This will have an impact on increasing the profitability of the company (Verawati and Juniarti, 2014: 124).

This study uses ROA as a tool to measure the profitability of the company. According to Hery, (2016.106) that the Return on Assets (ROA) is a ratio showing how much the contribution of assets in creating a net profit. In other words, this ratio is used to measure the amount of net income that will be generated from each rupiah funds that are embedded in total assets. This ratio is able to reflect how much the company has obtained returns on the financial resources invested by the company. The higher the return on assets is the higher the amount of net income resulting from any funds invested in total assets. Conversely, if the return on assets is low, the lower the profit generated by the funds invested in the total assets owned.

Debt to Equity Ratio (DER) is useful for knowing the amount of funds provided by the borrower (creditors) and the business owner in the sense that this ratio functions to determine each rupiah of its own capital that is used as debt collateral, the source of company funds is reflected by foreign capital and own capital (Kasmir, 2013: 157) "so, if the Debt to Equity Ratio (DER) is higher, then the company's ability to obtain profitability will be lower, so the increase in Debt to Equity Ratio (DER) will cause the Return on Asset (ROA) decreased (Kusumajaya 2011).

In addition, the size of the firm (Firm Size) including the factors affecting the level of profitability. Company size (Firm Size) is a description of the company as seen from the company's total assets. The higher total assets indicate the greater the property owned by the company so that investors are more interested to invest their shares. Company size describes the size of a company which can be expressed by total sales. The size of the company reflects the level of a company's operating activities. In general, the larger the company the greater the economic activity. Companies scale reflected in the reduction of production costs in line with the increase in the large production quantity. The bigger the Firm size, the greater the company's operating activities, which means the higher the company's ability to generate profitability.

\section{Literature REVieW}

This study is based on the research of Anisa Nursatyani (2014) The results show Debt to Total Asset (DTA), Current Ratio (CR), and assets tangibility have negative effect on Return on Assets (ROA), but firm size has no effect on Return on Assets (ROA). Current Ratio (CR) has negative effect on Debt to Total Assets (DTA), but firm size and asset tangibility have not effect on Debt to Total Assets (DTA). Debt to Total Assets (DTA) is able to mediate relationship between Current Ratio (CR) to Return on Assets (ROA), but is not able to mediate relationship between firm size and assets tangibility to Return on Asset (ROA.)

Husna (2016) found that based on the analysis and discussion of the results of hypothesis testing, the conclusion is that Firm Size has a significant effect on Return on Assets (ROA), while Growth Opportunity has no significant effect on Return on Asset, and Total Asset Turn Over has a significant effect on Return on Asset.

Febriani (2019) on the studies proved that directly Firm Size significant negative effect on Return on Assets, Growth Opportunity has no effect on Return on Assets, Firm Size positive 
and significant impact on the Dividend Payout Ratio, Growth Opportunity does not affect the Dividend Payout Ratio, Return on Assets not affect the Dividend Payout Ratio, firm Size directly influence Dividend Payout Ratio without mediated by Return on Assets, Growth Opportunity does not directly influence Dividend Payout Ratio, but must be mediated by Return on Assets, the company sub automotive sector registered The Indonesia Stock Exchange.

Ramadani (2020) on the research results show that the Debt to Asset Ratio (DAR) positive and significant impact on Return on Assets (ROA), Debt to Equity Ratio (DER) a significant negative effect on Return on Assets (ROA) and sales growth has a significant effect on Return on Assets (ROA). Based on the simultaneous testing indicates that the variable Debt to Asset Ratio (DAR), Debt to Equity Ratio (DER) and sales growth significantly influence the Return on Assets (ROA).

Furthermore Setyaningsih (2018) on the results of his research shows that the variable DER partially no significant influence on the CR partially ROA. While simultaneously DER and CR a significant influence on ROA of $84.3 \%$ in PT. Midi Utama Indonesia, Tbk.

Armyta (2020) on the results of hypothesis testing Current Ratio show that variable and significant effect on Company Size and Return on Assets, while the variable Total Asset Turn Over and Sales Growth has no effect on Return on Assets.

Aris (2016) on the results of his research shows that partially company size has a significant negative effect on ROA. Islamic Banking and partially Zakat significant positive effect on ROA. While simultaneously, variable size Zakat Islamic Banking Company and significant effect on the ROA of $45.5 \%$, while the remaining $54.5 \%$ is influenced by other factors not included in the research model.

Furthermore, Wibowo (2019) found that Firm Size (Ln Total Asset) has a positive and significant effect on financial performance (ROA), the Leverage Ratio (DAR) has a negative and significant effect on financial performance (ROA), the Leverage Ratio (DER) has a negative and insignificant effect. The financial performance (ROA) and firm Size (Ln Total Assets) and Leverage Ratio (DAR and DER) simultaneously significant affect the financial performance (ROA) in mining companies.

Efendi (2017) in his research results show that partially the DER variable affects ROA and ROE, and partially the DAR variable affects ROA and has no effect on ROE. The study was limited only done at any banking company and within a period of 3 years, should be able to use other enterprise sectors and over longer periods of time.

Hasmirati (2019) on the results obtained in this study is the simultaneous current ratio, debt to equity ratio and significant affect the return on assets. Partially current ratio and significant negative affect on return on assets, while debt to equity ratio and significant positive effect on return on assets.

Dewa Ayu Sri Yuartini (2016) who researched about Effect of Financial Ratios Financial Performance Against Banking Sector in Indonesia Stock Exchange, shows that the variable CAR, NPL and LDR states that the CAR, NPL and LDR have a negative effect on (ROA).

Muh Sabir (2012), who researched about Influence on Performance Ratio Finance Banks Islamic Banks and conventional bank in Indonesia. indicates that the variable ROA, NOM, NPF, FDR, NIM, ROA Against NPL and LDR states that a variable, ROA, NPF, NPL LDR and no significant negative effect on ROA and NIM while variable CAR positive and significant impact on ROA..

Ester (2011) who examined about Analysis of the Financial Ratio on the Performance of Commercial Banks in Indonesia, shows that the variables CAR, NPL, NIM, BOPO and LDR on ROA show that NPL, NIM and BOPO have a significant effect on ROA while the CAR and LDR variables have no significant effect on ROA.

Sutrisno (2018) in his research results show that the variables that affect (ROA) of Return on Assets of Banks Listed on the Indonesia Stock Exchange are NPL, while other variables examined in this study such as DER, CAR and LDR are not proven to affect ( ROA) Return on Assets. 
Indrawan (2018) in his research Debt to equity ratio has a partially significant effect on return on assets (ROA) in pharmaceutical sub-sector companies listed on the Indonesia Stock Exchange for the period 2012-2016 with a t-test result of -5.671 with a significant level of 0.000.

Aulia (2020) found the Current Ratio positive and significant impact on the return on assets in the cooperative in Palembang. Debt to Equity Ratio significant negative effect on the return on assets in the cooperative in Palembang. Debt to Total Assets Ratio significant negative effect on the return on assets in the cooperative in Palembang Period. Current Ratio, Debt to Equity Ratio and Debt to Total Assets Ratio together have a positive and significant effect on Return on Assets in cooperatives in Palembang City.

Rahayu (2016) in the conclusion of his research results DER, FS partially has a significant effect on ROA of mining companies listed on the Indonesia Stock Exchange, while partially CR does not have a significant effect on ROA of mining companies listed on the Indonesia Stock Exchange. DER, CR, FS simultaneously have a significant effect on ROA in manufacturing companies listed on the Indonesia Stock Exchange. The results of Dogan's (2013) research show that firm size has a positive effect on ROA.

\section{Data and Methodology}

3.1. Types of research. This research uses quantitative approach and uses statistical calculation technique. In this case, the quantitative approach is done by analyzing the Debt to Equity Ratio (DER) and Firm Size Variables data on the impact on Return on Asset (ROA) in Manufactured Company Listed at BEI period 2017-2019.

3.2. Population and Sample. Based on the data that researchers get that the population in this study is the data of Debt to Equity Ratio (DER) and Firm Size Variables and Return on Asset (ROA) in Manufactured Company Listed at BEI. Samples in this study are 172 companies in Manufactured Company Listed at BEI period 2017-2019. Source of data obtained in this research is in the form of secondary data. Secondary data that writer use is taken from UKDW Stock Exchange Corner period 2017-2019. The number of companies used in this study were 127 company samples.

\subsection{Operational Definition and Variable Measurement.}

3.3.1. Debt to Equity Ratio. Debt to equity ratio is the ratio to measure how much the company's capital is financed by total debt. The higher this ratio, the greater the amount of loan capital used as investment in assets in order to generate profits for the company. DER can be obtained from total debt divided by total capital. This ratio for the company will be better when it comes to the feasibility and financial risks of the company. The formula for finding debt to equity is as follows:

$$
D E R=\frac{\text { Total_Debt }}{\text { Total_Equity }}
$$

3.3.2. Firm Size. Firm size is one of the factors that influence the company's earnings management. Firm size is the scale of the company as seen from the company's total assets at the end of the year. Total sales can also be used to measure the size of the company. Because costs that follow sales tend to choose accounting policies that reduce profits. The size of the company can use the asset measure, because the company's total assets are large, so this can be simplified by transforming it into a natural logarithm. This variable can be measured by the following formula:

$$
\text { Size }=\ln T A
$$


3.4. Return on assets. Return on assets (ROA) is used to measure the company's ability to generate profits by generating profit using the total assets (assets) owned by the company after adjusting for the costs to fund these assets. This variable can be measured by the following formula:

$$
R O A=\frac{\text { Net_Income }}{\text { Total_Assets }}
$$

\subsection{Data Analysis Technique.}

3.5.1. Statistic analysis. The results of this data processing is used to answer the problems that have been formulated. This analysis is used to show the relationship between the independent variable $(\mathrm{X})$ with the dependent variable $(\mathrm{Y})$. Statistical analysis includes:

\section{Classic Assumption Test}

In this study, researchers will perform statistical tests regression in studying the relationship that exists between the variables are not free if the independent variables are known or vice versa. In practice there are four most commonly used classical assumption assays:

1.1. Normality Test

This test is done to see if the distribution of data available is normally distributed/not. One of the statistical tests that can be used to test residual normality is non-parametric statistical test Kolmogorov-Smirnov (K-S). The K-S test is done by hypothetical:

Ho : The residual data is normally distributed

Ha : Residual data is not normally distributed

Decision-making guidelines:

a. Sig value or significance or probability value $<0.05$. Distribution is not normal.

b. Sig value or significance or probability value $>0.05$. Distribution is normal.

1.2. Multicollinearity test

Multicollinearity test aims to test whether the regression model found the correlation between independent variables (independent). If independent variables are correlated, these variables are not orthogonal. To detect the presence or absence of symptoms of multicollinearity can be seen from the tolerance and VIF (variance inflation factor). If a low tolerance value is equal to a high VIF value, then it indicates a high collinearity (because VIF $=1$ / Tolerance). Common Cutoff values used to indicate the presence of multicollinearity are tolerance values $<0.10$ or equal to VIF value $>10$.

\subsection{Heteroscedasticity Test}

Heteroscedasticity test aims to test whether in the regression model there is a variance inequality of one observation residual to another observation. To test whether the variant of residual homogeneous use Spearman rank test, that is by correlating the five independent variables to the absolute value of the residual (error). If there is a significant independent variable correlation coefficient at error rate of $5 \%$, indicating the occurrence of heteroscedasticity.

1.4. Autocorrelation Test

Autocorrelation test aims to test whether in the linear regression model there is a correlation between the confounding error in period t with the intruder error in period t-1 (previous). The way used to diagnose autocorrelation is by Durbin-Watson test (DW test). Decision-making whether or not there is autocorrelation (Imam Ghozali, 2013) is:

a. If DW is located between the upper bound (Upper bound / $\mathrm{d}_{u}$ ) and $4-\mathrm{d}_{u}$, then there is no autocorrelation.

b. If DW is lower than the lower limit (Lower bound $/ \mathrm{d}_{l}$ ) then there is a positive autocorrelation.

c. If the DW value is greater than $\left(4-\mathrm{d}_{l}\right)$, then there is a negative autocorrelation.

d. If the DW value lies between $\left(4-\mathrm{d}_{u}\right)$ and between $\left(\mathrm{d}_{l}-\mathrm{d}_{u}\right)$ then the result cannot be concluded.

2. Simple Linear Regression Test 
Regression can be used to predict how far the value of the dependent variable changes, if the value of the independent variable is changed. Regression analysis, in addition to being used to measure the strength of the relationship between two variables, can also indicate the direction of the relationship between the dependent variable and independent variables.

The general equation of simple linear regression is:

$$
Y=\alpha+\beta X_{1}+\beta X_{2}+\varepsilon
$$

Explanation :

$\mathrm{Y}=$ Return on Asset (ROA)

$\alpha=$ Constant, is the value of $\mathrm{Y}$ when $\mathrm{X}=0$

$\beta=$ The direction of the regression coefficient, which states the change in the value of $\mathrm{Y}$ if there is a change of $\mathrm{X}$ value. If $(+)$ then the direction of the line will rise, and if $(-)$ then the value of the line will drop

$\mathrm{X}_{1}=$ Debt to Equity Ratio (DER)

$\mathrm{X}_{2}=$ Firm Size

$\varepsilon=$ other factors affecting variable $\mathrm{Y}$

\section{Hypothesis Testing}

The statistical test t basically shows how far the influence of a partially independent variable in explaining the dependent variable. This test is a two-way test with the hypothesis:

Ho : $\beta_{1}=0$ meaning there is no influence from independent variable to dependent variable.

H1 : $\beta_{1}<0$ or $\beta_{1}>0$ meaning there is influence from independent variable to dependent variable.

To calculate the value of $\mathrm{t}$ arithmetic used the formula:

$\mathrm{T}$ Count $=\beta_{1}$ Se $\left(\beta_{1}\right)$

Wherein:

$\beta_{1}=$ correlation coefficient

Se $\left(\beta_{1}\right)=$ standard error regression coefficients

Testing criteria:

a. $\mathrm{H} 0$ is accepted and $\mathrm{H} 1$ is rejected if $\mathrm{t}$ count $<\mathrm{t}$-table, meaning that independent variable has no significant effect to dependent variable.

b. $\quad \mathrm{H} 0$ rejected and $\mathrm{H} 1$ accepted if $\mathrm{t}$ count $>\mathrm{t}$-table, meaning that independent variables significantly influence the dependent variable. Another alternative to see the effect of partial is to see the significance value, if the value of significance formed under $5 \%$ then there is a significant influence of independent variables partially to the dependent variable. Conversely, if the significance is formed above $5 \%$ then there is no significant effect of independent variables partially to the dependent variable.

Hypothesis proposed and which will be tested are as follows:

H1 : Debt to Equity Ratio has a significant and negative effect on Return on Assets.

\section{H2 : Firm Size has a significant and positive effect on Return on Asset.}

\section{Results And Discussion}

\subsection{Analysis. 1. Classic Assumption Test Result}

\subsection{Normality Test}

The results of normality test (Kolmogorov-Smirnov test) can be seen in table 1 below:

Table 1: Normality Test Results (Kolmogorov-Smirnov Test)

\begin{tabular}{|c|c|c|}
\hline Sample & Significance & Result \\
\hline 172 & 0.200 & H0 accepted \\
\hline \multicolumn{2}{|c|}{ Source: Data processed by the authors. } \\
\hline
\end{tabular}

Result of normality test (Kolmogorov-Smirnov test) in table 1 above shows that without symptoms value. Sig. for 0.200 , this shows that the sig value is greater than the trust value (a 
$=0.05)$. Therefore it can be concluded that Ha is rejected and receives $\mathrm{H} 0$ so that the residual data is normally distributed.

1.2. Multicollinearity Test

Multicollinearity test results (VIF test) can be seen in table 2 below:

Table 2: Multicollinearity Test Results (VIF test)

\begin{tabular}{|c|c|c|}
\hline Independent variable & Tolerance & VIF \\
\hline DER & 0.988 & 1.012 \\
\hline Firm Size & 0.988 & 1.012 \\
\hline
\end{tabular}

Multicollonierity test results (VIF test) In Table 2 it shows that VIF value is less than 10 and tolerance is more than 0.1 which means that the regression model does not contain multicollinearity.

1.3. Heteroscedasticity Test

The results of heteroscedasticity test (Glejser test) can be seen in table 3 below:

Table 3: Heteroscedasticity Test Results (Park Test)

\begin{tabular}{|c|c|c|}
\hline Variable & Significance & Result \\
\hline DER & 1.000 & Non Heteroscedasticity \\
\hline Firm Size & 1.000 & Non Heteroscedasticity \\
\hline \multicolumn{2}{|c|}{ Source: Data processed by the authors. } \\
\hline
\end{tabular}

The result of heteroscedasticity (Glejser test) in Table 3 above shows that the independent variable has a sig value above $\alpha(0.05)$. Therefore it can be concluded that the regression model there are no symptoms of heteroscedasticity on DER and Firm Size Variables.

1.4. Autocorrelation Test

The autocorrelation test results can be seen in table 4 below:

Table 4: Autocorrelation Test Results (Run Test)

\begin{tabular}{|c|c|c|}
\hline Sample & Significance & Conclusion \\
\hline 172 & 0.167 & H0 accepted \\
\hline
\end{tabular}

\section{Regression Test Result}

Table 7: Regression Test Result

\begin{tabular}{|c|c|c|c|}
\hline Variable & T & Significance & Result \\
\hline DER & -3.324 & 0.001 & H1 Accepted \\
\hline Firm Size & -2.000 & 0.047 & H2 Accepted \\
\hline
\end{tabular}

Based on the results of Regression testing the effect of Debt to Equity Ratio (DER) ( $\mathrm{X}_{1}$ ) on Return on Asset (ROA) (Y) by using SPSS program obtained t-count -3.324 with $\mathrm{p}$ value 0.001, and effect of Firm Size $\left(\mathrm{X}_{2}\right)$ on Return on Asset (ROA) (Y) by using SPSS program obtained t-count -2.000 with p value 0.047 so it can be concluded $\mathrm{H} 1$ and $\mathrm{H} 2$ accepted. This shows that there is a negative and significant influence of Debt to Equity Ratio (DER) $\left(\mathrm{X}_{1}\right)$ on Return On Asset (ROA) (Y) and there is a Positive and significant influence of Firm Size $\left(\mathrm{X}_{2}\right)$ on Return on Asset (ROA) (Y).

4.2. The Effects of Debt to Equity Ratio (DER) To Return on Asset (ROA). Based on the results of the test using regression Test the effect of Debt to Equity Ratio (DER) on Return on Asset (ROA) using SPSS program obtained t-count -3.324 with p value 0.001. H1 hypothesis built on this variable is Debt to Equity Ratio (DER) has a negative and significant effect on the variable Return on Asset (ROA). Because the value of $\mathrm{p}$ value $0.017<0.05$ can be concluded H1 accepted. This shows that Debt to Equity Ratio (DER) has a negative and significant effect on Return on Asset (ROA).

Based on the partial results of research found that the variable (DER) having an negative and significant (ROA). Based on these results it can be concluded that (DER) cannot face the risks faced and closer to a debt covenant violations based accounting. This ratio is the 
percentage of provision of funds by shareholders to lenders. The higher the ratio indicates the lower the company's funding is provided by the shareholders. Debt Equity Ratio (DER) affect the return on assets because of the higher DER showed that the higher the use of debt as a source of corporate funding. This can cause an interest expense which is also quite large for the company, this causes the company's profits to decrease and of course this makes the ROA in the company smaller.

The result of this research is supported by Brigham and Houston (2009: 98) "If the costs incurred by loans are smaller than the costs of own capital, then the source of funds originating from loans or debt will be more effective in generating profits (increasing Return on Assets). This is also in line with research conducted by Hantono (2015) whose results show that the debt to equity ratio has a significant effect on profitability. Sudarsono (2007: 199) states that if companies use debt more than their own capital, the DER rate will decrease because the interest expense to be borne also increases. This has an impact on decreasing profitability. This study is in accordance with the findings of Ramadani, Setyaningsih, wibowo, Efendi, Hasmirati, Indrawan, Pearl and Rahayu.

This study contradicts with Eddy Mulyadi (2014), Effect of Liquidity and leverage to Profitability in Food and Beverage listed on the Indonesia Stock Exchange. This study shows that the ratio of liquidity and leverage has a positive and significant effect on profitability.

4.3. The Effect of Firm Size To Return on Asset (ROA). Based on the results of the test using regression Test the effect of Firm Size on Return on Asset (ROA) using SPSS program obtained t-count -2.000 with p value 0.047. H1 hypothesis built on this variable is Firm Size has a Positive and significant effect on the variable Return on Asset (ROA). Because the value of $\mathrm{p}$ value $0.047<0.05$ can be concluded $\mathrm{H} 2$ accepted. This shows that Firm Size has a Positive and significant effect on Return on Asset (ROA).

Based on the results of the study partially it is known that the Firm Size variable has a positive and significant effect on (ROA). This supports the theory that the company size factor as proxy by total assets shows that the size of the company is an important factor in the formation of profits. Large companies that are considered to have reached the maturity stage are an illustration that these companies are relatively more stable and more able to generate profits than small companies. the bigger the assets, the more capital invested, the more turnover of money and the size of the market capitalization, it will improve the company's financial performance. Large, well-established companies will find it easier to obtain capital in the capital market compared to small companies. Because the ease of access means that large companies have greater flexibility (Sartono, 2010). The better the quality of the financial statements presented, the more convincing external parties will see the company's financial performance, which automatically of course the parties associated with the company will feel satisfied in various matters with the company (Fahmi, 2013). The increase in Firm Size shows that the company is able to manage the resources owned by a large Firm Size which is getting better. A large Firm Size can increase the scale that is good for the economy. Large and established companies will be quite easy to enter the capital market, the ease with which the company has the capital market will increase investor confidence.

The results of the study are in accordance with the research conducted by (Riawan, 2019); (Kopong \& Nurzana, 2016) and (Manoppo \& Arie, 2016) who say that company size has a significant effect on Return on Assets. Based on the results of research conducted which is supported by previous research regarding the effect of Firm Size on Return on Assets, it can be concluded that there is a correspondence between the results of the study and previous research, namely the significant influence of Firm Size on Return on Assets. Firm Size has an influence on Return on Assets, as stated by Kartini and Arianto, the bigger the company, the bigger the assets owned, if the assets are bigger, the funds used are also bigger for operations, the bigger the operational, the bigger the impact tends to be. the income will also be greater which of course will be followed by the movement of the company's profit. This profit movement will 
definitely drive the company's ROA, therefore company size has an effect on ROA. This study is in accordance with the findings of Husna (2016) and Febriani (2019).

\section{Conclusion}

The result of Debt to Equity Ratio (DER) also has a significant effect on profitability measured by Return on Asset (ROA) in Manufactured Company period 2017-2019. Regression coefficient result shows negative relationship, that means if Debt to Equity Ratio (DER) increases then profitability of Manufactured Company will decline. The influence of Debt to Equity Ratio (DER) on Return on Equity (ROA) shows the high level of Debt to Equity Ratio (DER) in a Manufactured Company can show the quality of unhealthy Manufactured Company. Thus, causing Debt to Equity Ratio (DER) in Manufactured Company can give an illustration will negatively affect the profitability of Manufactured Company. The influence of Firm Size on Return on Equity (ROA) shows the high level of Firm Size in a Manufactured Company can show the quality of unhealthy Manufactured Company. Thus, causing Firm Size in Manufactured Company can give an illustration will negatively affect the profitability of Manufactured Company.

\section{Limitation}

The limitation in this study is the selection of the independent variables used in this study, namely the debt to equity ratio and firm size, to further research it can add other variables that are considered influencing the return on assets so that it is possible can produce conclusions that are different from the original hypothesis there is.

\section{RECOMMENDATION}

Future studies are expected to researchers can add the variables, sector companies, the sample and add the study period.

\section{REFERENCES}

[1] Aris, Yoga Aris. 2016. "Pengaruh Ukuran Perusahaan dan Zakat Perbankan Syariah Terhadap Return On Asset." Ekonomi \& Bisnis 15, no. 1: 35-42.

[2] Armyta, Zulfa Khusnul, and Yuli Chomsatu Samrotun. 2020. "Faktor-Faktor yang Mempengaruhi Return On Assets." JRB-Jurnal Riset Bisnis 3, no. 2: 124-130.

[3] Aryanti, Fitri. 2017. "Pengaruh Struktur Modal, Ukuran Perusahaan, dan Pertumbuhan Perusahaan Terhadap Profitabilitas Pada Perusahaan Yang Tergabung dalam LQ 45 Di Bursa Efek Indonesia Tahun 2013-2015." Jurnal Online Mahasiswa (JOM) Bidang Manajemen 1, no. 1.

[4] Aulia, Mutiara, Harsi Romli, and Luis Marnisah. 2020. "Pengaruh Current Ratio, Debt Equity Ratio dan Debt To Asset Ratio Terhadap Return On Asset Pada Koperasi di Kota Palembang." Integritas Jurnal Manajemen Profesional (IJMPRO) 1, no. 1: 27-38.

[5] Brigham, Eugene F., and Joel F. Houston. 2010. Dasar-dasar manajemen keuangan (Essential of financial management). Edisi 11-buku 1. Jakarta: Salemba Empat.

[6] Soepardi, Eddy Mulyadi. 2014. "Analisis Likuiditas Dan Leverage Terhadap Profitabilitas Perusahaan Yang Terdaftar Di Bursa Efek Indonesia." MAGMA: Jurnal Magister Manajemen 2, no. 1.

[7] Efendi, Azzalia Feronicha Wianta, and Seto Sulaksono Adi Wibowo. 2017. "Pengaruh Debt To Equity Ratio (DER) dan Debt To Asset Ratio (DAR) Terhadap Kinerja Perusahaan di Sektor Keuangan yang Terdaftar di Bursa Efek Indonesia." Journal of Applied Managerial Accounting 1, no. 2: 157-163.

[8] Fahmi, Irham. 2013. Analisis Laporan Keuangan. Bandung: Alfabeta.

[9] Febriani, Ade, and Maya Sari. 2019. "Pengaruh Firm Size dan Growth Opportunity Terhadap Return on Assets dan Dividend Payout Ratio." Maneggio: Jurnal Ilmiah Magister Manajemen 2, no. 2: 184-199.

[10] Ghozali, Imam. 2013. "Aplikasi Analisis Multivariate dengan Program IBM SPSS 21 Update PLS Regresi. semarang: Badan penerbit Universitas Diponegoro." Information Technology 2, no. 2.

[11] Hasmirati, Hasmirati, and Alfin Akuba. 2019. "Pengaruh Current Ratio Dan Debt To Equity Ratio Terhadap Return on Assets Pada Perusahaan Manufaktur Yang Terdaftar Di Bursa Efek Indonesia." SIMAK 17, no. 01: 32-41.

[12] Hery. 2015. Analisis Laporan Keuangan. Yogyakarta: CAPS.

[13] Husna, Nailal. 2016. "Analisis Firm Size, Growth Opportunity Dan Total Asset Turn Over Terhadap Return On Asset Kasus Pada Perusahaan Food Beverages." Jurnal Apresiasi Ekonomi 4, no. 1: 65-70. 
[14] Indrawan, A. 2018. Pengaruh Debt To Equity Ratio Terhadap Return on Asset (Roa) Pada Perusahaan Sub Sektor Farmasi Yang Terdaftar Di Bursa Efek Indonesia. Ummi, 12(3):. 5-16.

[15] Kartini, Kartini, and Tulus Arianto. 2008. "Struktur Kepemilikan, Profitabilitas, Pertumbuhan Aktiva dan Ukuran Perusahaan Terhadap Struktur Modal pada Perusahaan Manufaktur." Jurnal Keuangan dan Perbankan 12, no. 1.

[16] Maith, Hendry Andres. 2013. "Analisis Laporan Keuangan dalam Mengukur Kinerja Keuangan pada PT. Hanjaya Mandala Sampoerna Tbk." Jurnal EMBA: Jurnal Riset Ekonomi, Manajemen, Bisnis dan Akuntansi 1 , no. 3 .

[17] Kusumajaya, Dewa Kadek Oka. 2011. "Pengaruh struktur modal dan pertumbuhan perusahaan terhadap profitabilitas dan nilai perusahaan pada perusahaan manufaktur di bursa efek Indonesia." Universitas Udayana, Denpasar: Tesis yang Tidak Dipublikasikan.

[18] Nursatyani, Anisa, Sugeng Wahyudi, and Muhamad Syaichu. 2014. "Analisis Pengaruh Current Ratio, Firm Size, dan Assets Tangibility Terhadap Return On Asset Dengan Debt To Total Asset Sebagai Variabel Intervening (Studi pada Perusahaan Sektor Pertambangan yang Terdaftar di BEI Tahun 2008-2011)." Jurnal Bisnis Strategi 23, no. 2: 97-127.

[19] Rahayu, Septi Mauliddiana. 2016. "Analisis Pengaruh Debt To Equity Ratio, Current Ratio, Firm Size Terhadap Return On Asset Pada Perusahaan Pertambangan Yang Terdaftar Di Bursa Efek Indonesia Tahun 2012-2014." Jurnal Skripsi: 1-15.

[20] Ramadani, Dwi, and Sapto Jumono. 2020. "Analysis of Cash Position Effect, Debt to Equity Ratio, Return on Assets, And Loan to Deposit Ratio, Net Call Money Over Pay-out Ratio Dividends (Case Study of Banking Companies Listed on the Indonesia Stock Exchange in 2012-2018)." Journal of Multidisciplinary Academic 4, no. 3: 176-182.

[21] Salman, Muhammad. 2019. "Pengaruh Solvabilitas dan Pertumbuhan Penjualan Terhadap Profitabilitas Pada Perusahaan Logam dan Sejenisnya Yang Terdaftar di Bursa Efek Indonesia." Jurnal Penelitian Ekonomi Akuntansi (JENSI) 3, no. 2: 151-161.

[22] Sari, Ni Made Vironika, and I. G. A. N. Budiasih. 2014. "Pengaruh debt to equity ratio, firm size, inventory turnover dan assets turnover pada profitabilitas." E-Jurnal Akuntansi Universitas Udayana 6, no. 2: 261273.

[23] Setyaningsih, Eka Dyah, and Cucun Cunengsih. 2018. "Pengaruh debt to equity ratio dan current ratio terhadap return on assets Pada PT. Midi Utama Indonesia, Tbk." Account: Jurnal Akuntansi Keuangan dan Perbankan 5, no. 2.

[24] Setyaningsih, Eka Dyah, and Cucun Cunengsih. 2018. "Pengaruh debt to equity ratio dan current ratio terhadap return on assets Pada PT. Midi Utama Indonesia, Tbk." Account: Jurnal Akuntansi Keuangan dan Perbankan 5, no. 2.

[25] Sutrisno, Sutrisno. 2018. "Pengaruh Debt To Equity Ratio (Der), Capital Adequacy Ratio (Car), Non Performing Loan ( $\mathrm{Npl}$ ) Dan Loan To Deposit Ratio (Ldr) Terhadap Return On Assets (Roa) Pada Bank Yang Terdaftar Di Bursa Efek Indonesia." Jurnal Stie Semarang (Edisi Elektronik) 10, no. 3: 56-72.

[26] Sutrisno. 2017. Manajemen Keuangan. Yogyakarta: Ekonisia.

[27] Hansen, Verawati. 2014. "Pengaruh Family Control, Size, Sales Growth, dan Leverage terhadap Profitabilitas dan Nilai Perusahaan pada Sektor Perdagangan, Jasa, dan Investasi." Business Accounting Review 2, no. 1: 121-130.

[28] Wibowo, Nasib. 2019. "Pengaruh Firm Size Dan Leverage Ratio Terhadap Kinerja Keuangan Pada Perusahaan Pertambangan." Jurnal Wira Ekonomi Mikroskil: JWEM 9, no. 1: 13-20. 